DIPLOMACY OF CONSCIENCE 
This page intentionally left blank 


\title{
DIPLOMACY OF CONSCIENCE
}

\author{
AMNESTY INTERNATIONAL AND \\ CHANGING HUMAN RIGHTS NORMS
}

ANN MARIE CLARK

\author{
PRINCETON UNIVERSITY PRESS \\ PRINCETON AND OXFORD
}


Copyright @ 2001 by Princeton University Press

Published by Princeton University Press, 41 William Street,

Princeton, New Jersey 08540

In the United Kingdom: Princeton University Press,

3 Market Place, Woodstock, Oxfordshire OX20 1SY

All Rights Reserved.

\section{Library of Congress Cataloging-in-Publication Data}

Clark, Ann Marie

Diplomacy of Conscience: Amnesty International and

Changing Human Rights Norms / Ann Marie Clark

p. cm.

Includes bibliographical references and index.

ISBN 0-691-05742-7 (cloth : alk. paper) — ISBN 0-691-05743-5 (pbk. : alk. paper)

1. Amnesty International. 2. Human rights. I. Title

JC571.C613 2001

$323^{\prime} 06^{\prime} 01-\mathrm{dc} 21$

00-056509

This book has been composed in Baskerville

The paper used in this publication meets the minimum requirements

of ANSI/NISO Z39.48-1992 (R1997) (Permanence of Paper)

www.pup.princeton.edu

Printed in the United States of America

$\begin{array}{llllllllll}10 & 9 & 8 & 7 & 6 & 5 & 4 & 3 & 2 & 1 \\ 10 & 9 & 8 & 7 & 6 & 5 & 4 & 3 & 2 & 1 \\ \text { (pbk) } & & & & & & & & \end{array}$




\section{For JAM and my parents}

The chances of factual truth surviving the onslaught of power are very slim indeed; it is always in danger of being maneuvered out of the world not only for a time but, potentially, forever. (Hannah Arendt, Between Past and Future, 231) 
This page intentionally left blank 